\title{
The Role of Technical Museums in the Regeneration of Industrial Functionally - Restructured Regions (Romania)
}

\author{
Merciu CristinaA*, Cercleux LoretaA, Peptenatu Daniel ${ }^{\mathrm{A}}$, \\ Merciu George ${ }^{B}$, Drăghici Cristian ${ }^{A}$, Pintilii Radu ${ }^{A}$
}

Received: December 2011 | Revised: April 2012 | Accepted: May 2012

\begin{abstract}
The main purpose of the study is to depict the evolution of technical museums across Romania, highlighting a new trend - visible in the past few years - towards preservation of industrial heritage assets in areas that have undergone functional reorganization. This trend is the result of the country's adaptation to the new socio-economic conditions, but also an accession into the stage of cultural and touristic capitalization on industrial heritage assets, acting as a support-activity in boosting the economy of disadvantaged industrial areas. The second purpose of the study consists of elaborating a critical analysis of technical museums from Romania in order to identify the caracteristics to use to increase their cultural role. Also, the analysis is focused on the premise to make technical museums stand out as tourist attraction hubs and to preview their role in the redevelopment of industrial areas in decline, banking on a positive economic and socio-cultural impact.
\end{abstract}

Key words: industrial heritage, conversion, cultural regeneration, technical museums, Romania

\section{Introduction}

Museums are public cultural institutions that manage a historical patrimony with a certain specific nature, for educational purposes. New meanings were shaped up with the emergence of the first technical museums, with the emphasis switching from the idea of a collection of items with historical value towards the idea of an instrument to understand the functionality of man-made technical achievements.

In the past few years technical museums specializing in the preservation of the industrial heritage increased their cultural role by a function as instrument in the redevelopment of regions that underwent functional restructuring. Museum and cultural organizations have been recognized as a value for the vitality and character of cities particularly within the idea of "urban regeneration", that includes the challenge to achieve long-term, strategic reshaping of cities and neighbourhoods, set against a history of short-term, area-based initiatives. Cultural investments, merging tourism strategies with local capability creation, have been seen, in this context, as effective catalysts for city regeneration processes (Bianchini, 1993, Geronimi, 2006).

The concept of cultural regeneration is a complex one, including, also, the preservation and cultural capitalization of abandoned industrial sites (Preite, Maciocco, 2000, Massarente, Ronchetta, 2004, Scott, 2007).

As it is well-known, the re-use of abandoned buildings for museums has been one of the key cultur-

\footnotetext{
A Interdisciplinary Center of Advanced Researches on Territorial Dynamics, University of Bucharest, Blvd Regina Elisabeta, 4-12, Bucharest, Romania;

B Faculty of Geography, University of Bucharest, Blvd. Nicolae Bălcescu, 1, Bucharest, Romania

* Corresponding author: Merciu Cristina, e-mail: krysten1009@yahoo.com
} 
al policies ever since the French Revolution (Lorente, 1996). The inventory process could create capitalization of industrial sites in the sense of its value for tourism (Đurović, Đurović, 2010). Changes of a cultural nature, focusing on the preservation of industrial patrimony assets, occurred as part of post-modernism, converting the ancient factories into museums (Lorente, 1996). At the level of "factory-towns" (Grandi, 1991) using the capacity of self-capitalization, new forms of activity can be reinvented that would involve a reconversion of the industrial physical capital, by means of its capacity to create value, not only inside the industrial facility but inside the entire social life that composes the mystique of the value of labour, integrated into the miners' culture (Grandi, 1991 quoted in Merciu, 2010). Also, the development of heritage tourism is understood not only as one of the pillars of alternative economic and social development to replace the deactivated mining industry, but also an active agent in the process of defining the diverse collective identities (Ballesteros \& Ramirez, 2007 quoted by Gorjup-Kavčič et al, 2010).

This study is centered on the analysis of the evolution of technical museums in Romania, which, in terms of the manner of their design and layout, reflect the changes that occurred in Romanian society, changes marked by the transfer from the centralized regime to free-market economy. At the same time, the approach of this study is focused on the analysis of the role technical museums in Romania can play in the redevelopment of industrial areas that have undergone a functional reorganization.

\section{Methodology}

In order to elaborate the study, a nationwide inventory of all technical museums was conducted, with the purpose of highlighting their characteristics and forms of promotion. The second purpose of the fieldwork research done was to visit new technical museums, established since 1990 and homologated or pending homologation. Later on the technical museums were analyzed from the point of view of the impact they generate on the area where they are located, from the point of views of both the economy and their quality as cultural landmarks generated by industry.

One of the goals of the study consists in the interpretation of technical museums from the perspective of the process of inclusion into the patrimony, as they are defining elements of industrial social communities, preserving and to the same extent evoking local identity. Starting the late 1990s, geographers have joined the trend of patrimony research, significantly later than other social sciences (Veschambre, 2007).
The study applies the methodology based in the use of patrimony assets in the analysis of the processes to reclaim and capitalize on spaces deemed economically inefficient, in the wake of economic reorganization.

\section{The characteristics of Romanian technical museums}

There are a total of 14 technical museums in Romania, closely linked to the evolution and cultural capitalization of the industrial heritage (Cercleux, Merciu, 2010): the "Dimitrie Leonida" Technical Museum, the Aviation Museum, the Romanian Railway Museum in Bucharest, the steam locomotive museums in Reşița ands in Sibiu, the oil museum and the watch museum in Ploieşti, the gold museum in Brad, the iron museum in Hunedoara, the mining museums in Petroşani and in Roşia Montană (Roman mining site Alburnus Maior), the "Ştefan Procopiu" Science and Technique Museum in Iaşi, the weaving museum in Bacău, the technical museum of the Reşița factories (fig. 1).

In terms of numbers, the categories of technical museums best represented in Romania are those dedicated to railway assets (3) and mining (3).

The analysis of the spatial distribution of technical museums in Romania reflects a strong connection to the areas that have undergone heavy industrialization. Thus, most technical museums are located inside industrial hubs (Bucharest, Reşiţa), but also in cities that have seen a relatively moderate development of industry (Bacău).

There are several examples of technical museums that have been established in industrial towns, where there is no direct connection between the nature of the museum and the basic industrial profile of the respective town: for instance the main industrial venture in the city of Sibiu was machine and textile production, yet since 1994 it has been host to the second steam-locomotive museum in Romania. The explanation as to the presence of the museum lies, on the one hand, in the interest in preserving railway patrimony assets, and on the other hand, to practical reasons: the existence of a space large enough to display the 17 locomotives that have been maneuvered into the premises of the museum, established inside the city roundhouse.

In terms of the period of time referred to, the technical museums in Romania are divided into two categories: museums built before and after the 1990s. A strictly temporal analysis fails to suggest, at a first glance, any changes in the typology of technical museums, if one does not take into account the changes of economic and social nature that occurred in the two time periods of reference, which highlight a series of differences, in terms of museum administration. 


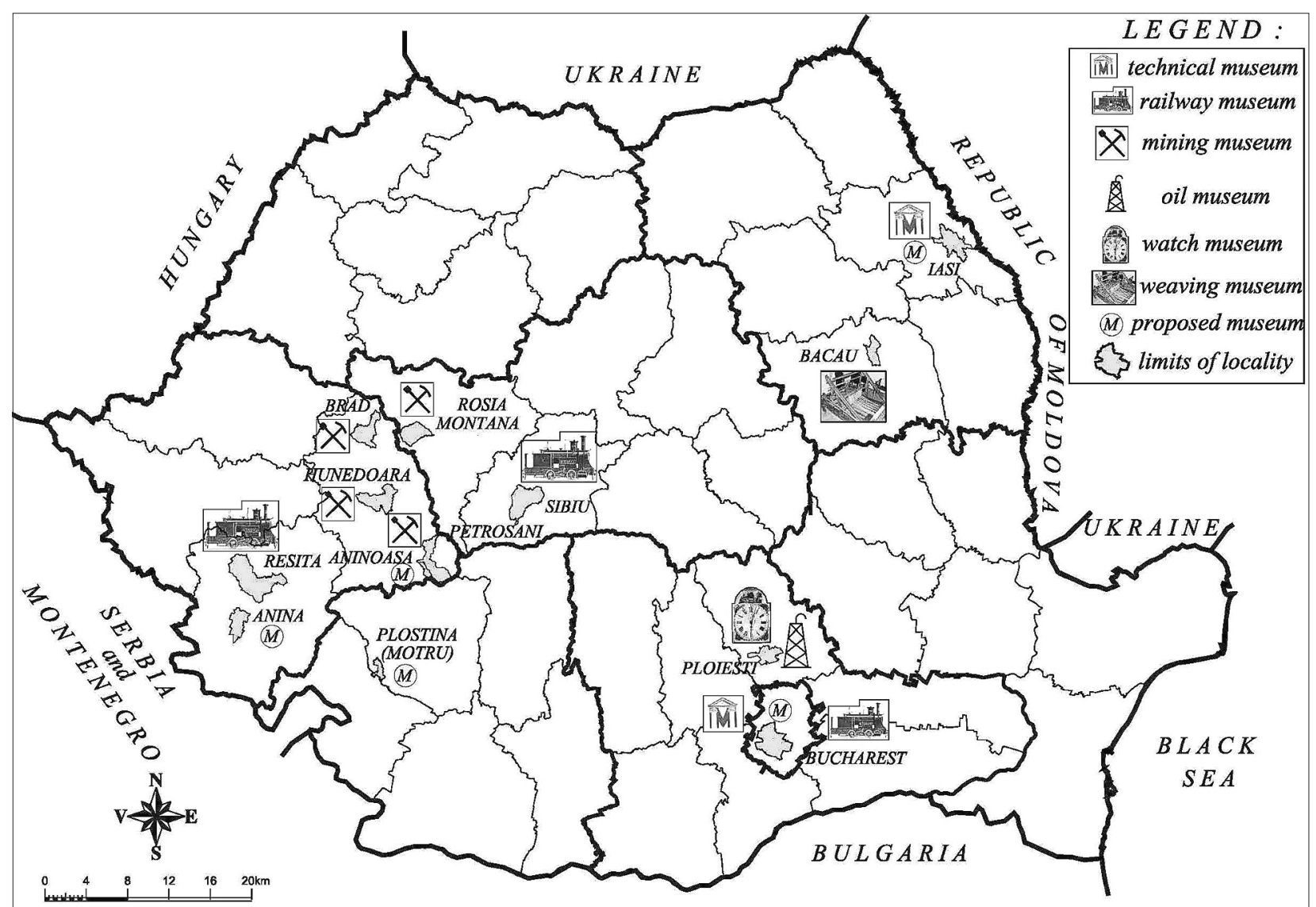

Figure 1. Distribution of technical museums across Romania

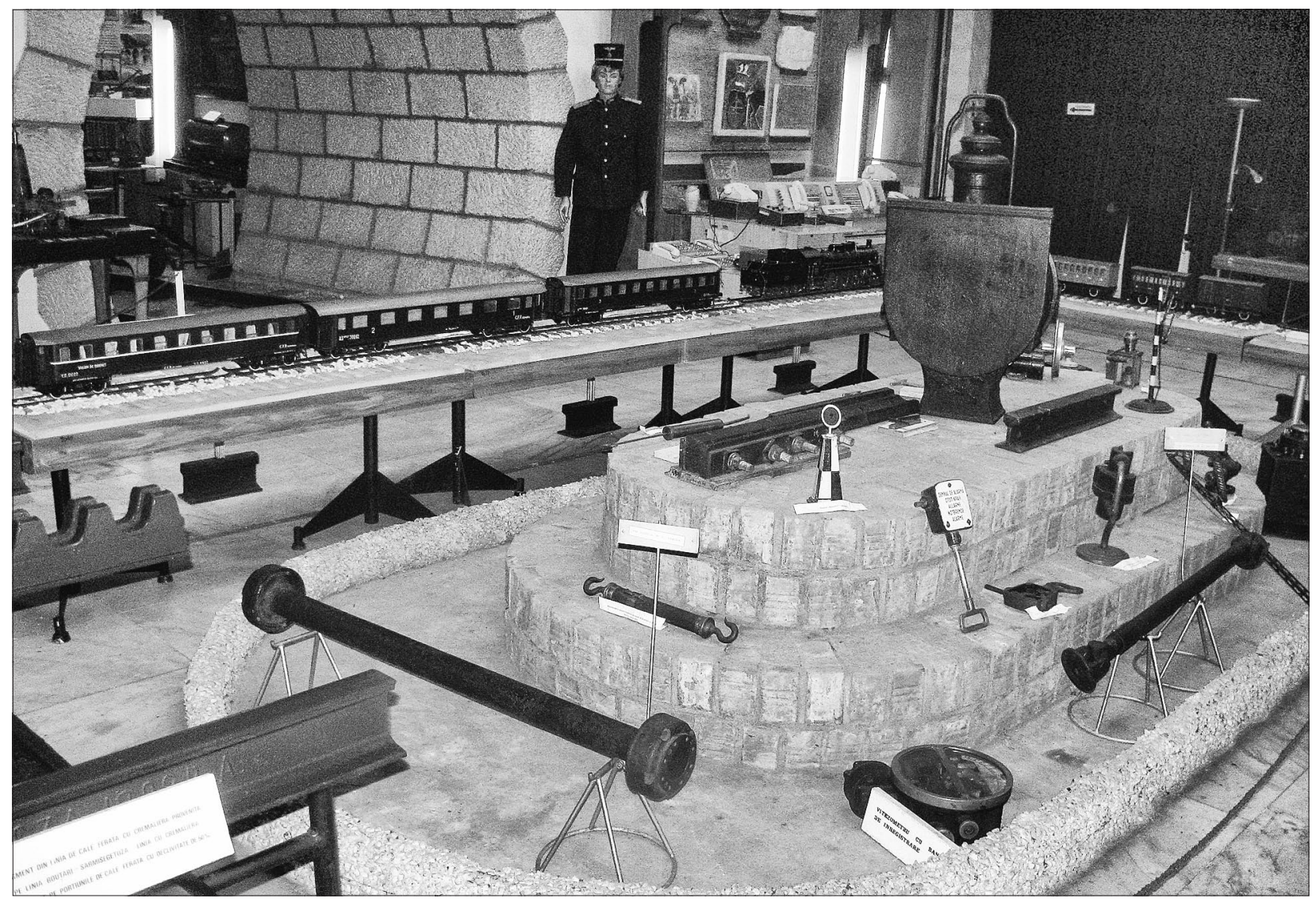

Figure 2. The Romanian Railways Museum - Bucharest 


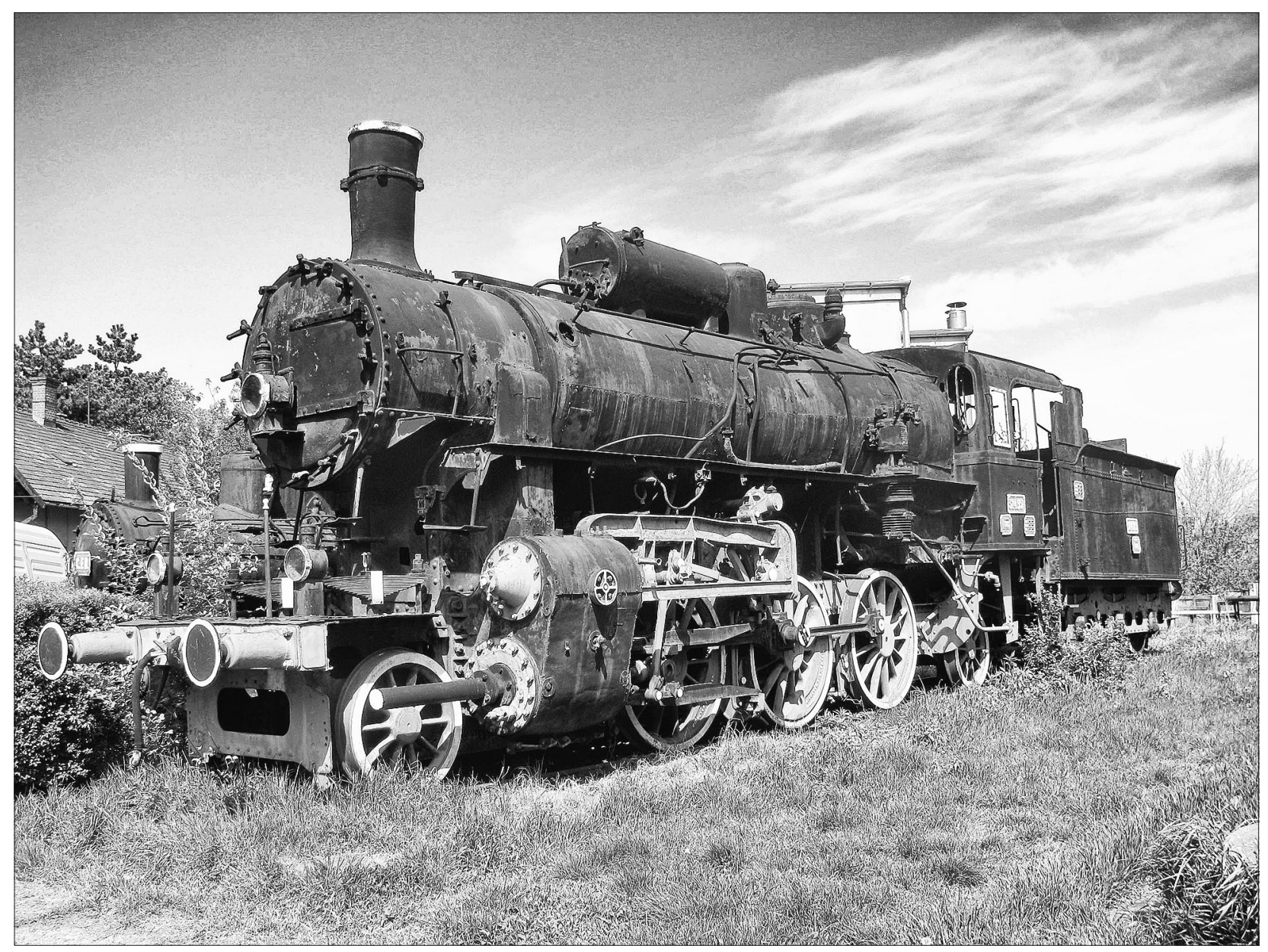

Figure 3. Steam locomotive at the Sibiu museum

While, until the 1990s, technical museums that "hosted" collections of industrial machines used to predominate, there was a noticeable diversification of technical museums in the past few years, represented by museums resulted from the conversion of decommissioned industrial facilities, and, respectively, from the in situ conservation of industrial heritage assets (for instance, establishment as a museum of the Alburnus Maior-Roşia Montană mining site, the inclusion in the tourist circuit of the former salt-mines: Târgu Ocna, Turda, and others), as well as the economic ventures where production is still undergoing: vineyards (wine and vineyard tourism), for instance the: Murfatlar, Recaş and Azuga vineyards and cellars, among others (Unguraş et al, 2009, Merciu, Stoica, 2010).

These examples reflect Romania's opening up to the Europe-wide trend to preserve and capitalize on the industrial patrimony assets in situ and ex situ (Merciu, 2011).

Five other suggested museums are added to the above-mentioned technical museums (fig. 1): in $\mathrm{Bu}-$ charest, there was a suggestion to establish a new railway museum inside the triangular area defined by Buzeşti-Berzei-Calea Griviței streets; a museum ded- icated to industrial archaeology, which is to be established in Iaşi, at the initiative of the specialist in cultural patrimony preservation at the "Ştefan Procopiu" Technical Museum; the museum will be laid out inside the former storehouse of the Ciurea brick factory in Iaşi; inside, various industrial heritage assets will be collected: old locomotives and traincars will be transported from the Nicolina Repair Shops in Iaşi, ands they will be displayed on a platform, with other heavy machinery, trams, heating installations (old water boilers, engines) displayed alongside (Cercleux, Merciu, 2010).

One other suggestions concerns the conversion of the Anina mine (Caraş Severin county) (fig. 5) in a mining museum, an action that would involve capitalizing on the machines and industrial installations used for the 200 years when the mine was in service.

The fourth suggestion for a technical museum has the goal of preserving the mining patrimony assets in Ploştina, a community located in the Motru mining region (Gorj county). The plans involve creating the museum using the Mining Museum in Petroşani as a model. The plans involve establishing that museum inside the school in the locality, which was recently closed down. 


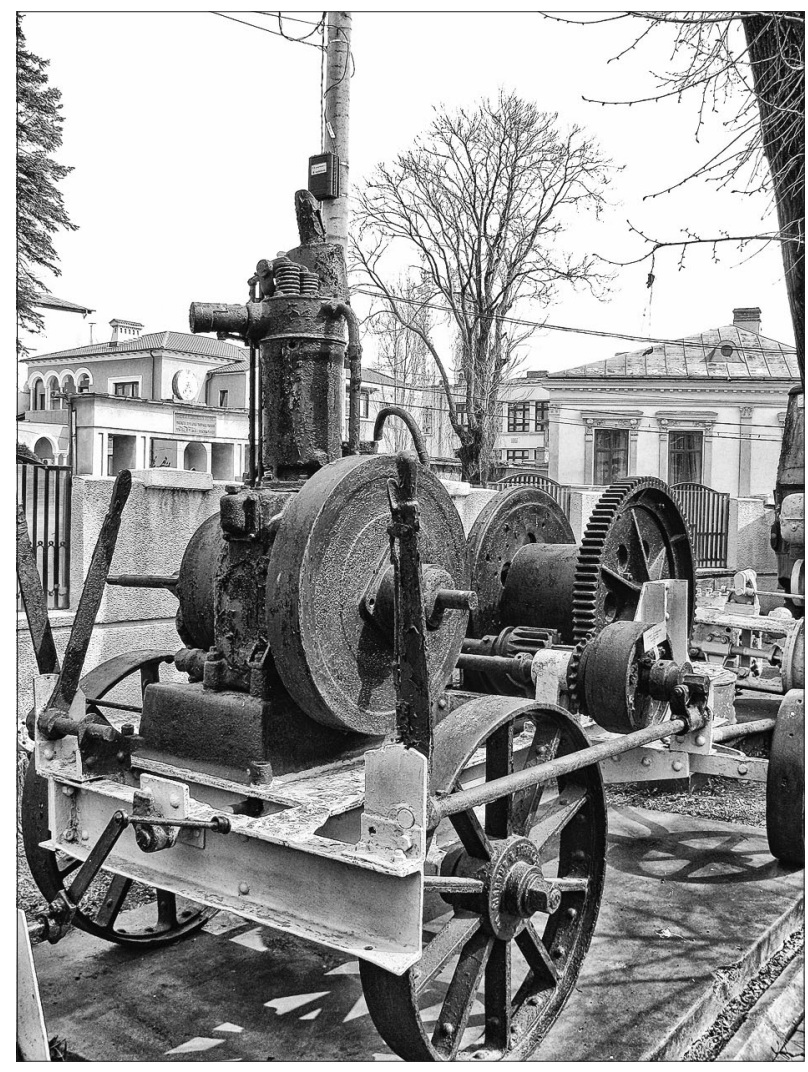

Figure 4. Bernard engine at the Oil Museum

One other example of museum capitalization of industrial heritage, which has moved past the planning stage, is the action to convert the Aninoasa mine (Hunedoara county) into a technical museum. Construction of the museum, begun in 2010, is expected to complete in 2011; it is being accomplished with the support of non-returnable funds granted by the World Bank (Merciu, 2011).

The suggestions to build the new technical museums reflect, on the one hand, the positive dynamics of the areas that have undergone functional reorganization, and respectively the stage of cultural preservation. On the other hand, the increase in the numbers of technical museums in Romania indicates a new phase in the evolution of industrial sites, representing a strategic approach to the alternative development of disadvantaged industrial areas, an action subordinated to tourist activity. Thus, the creation of technical museums by means of the conversion of industrial sites into cultural tourist attractions is a superior form of capitalizing on formerly industrial regions whose economy is on a decline.

\section{Results}

An analysis of the typology of technical museums inventoried at national levels indicates that these museums are associated with varied industrial operations (extractive, textile ventures), to rail transport as a sub-

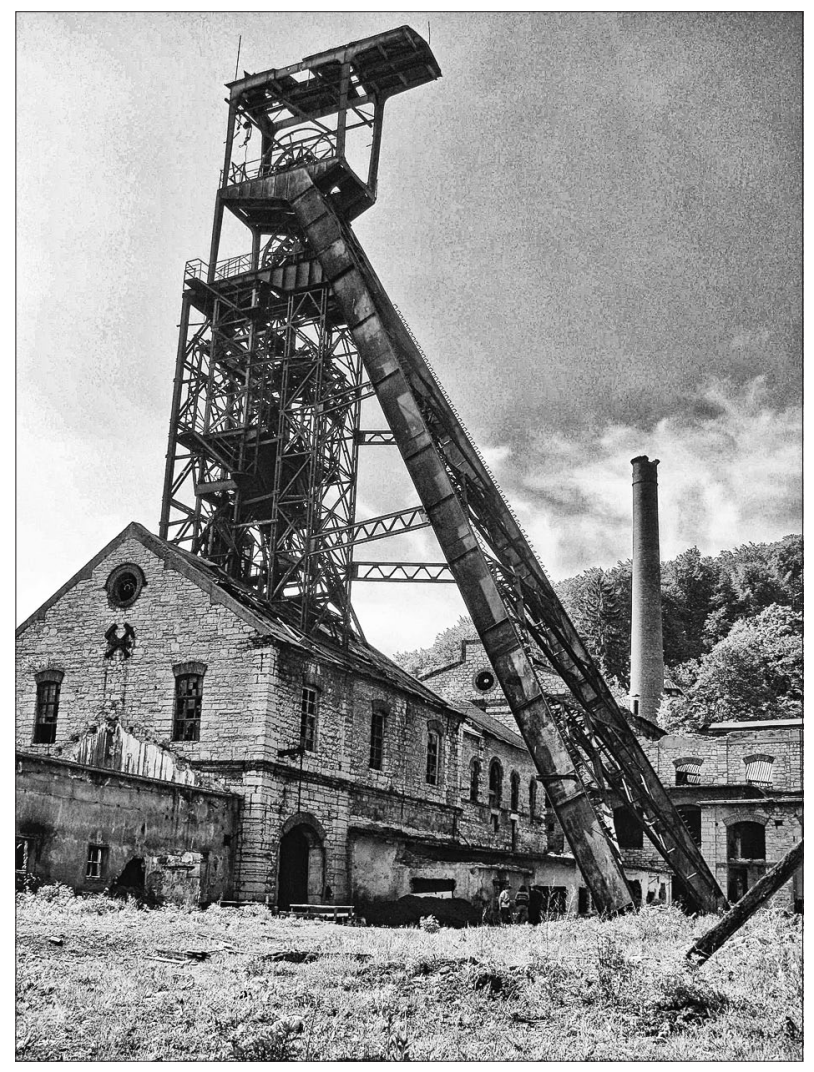

Figure 5. The main shaft of the Anina mine

type of the industrial heritage. Also, there are instances of museums that capitalize on the technical features of the industrialization process, which indicates the variety of the industrial patrimony assets across Romania, which define it as a complex cultural patrimony.

It is also worth noticing the presence of an important number of technical museums whose establishment was suggested, which are included, because of their nature, among cultural institutions whose purpose is to protect and promote the Romanian industrial heritage. They are meant to reflect the importance of the process of preservation of the industrial heritage asserts across Romania, by means of the openness towards this category of the national cultural as well as by means of their diversity; however, most of them are included in the category of museums that are associated to the preservation in situ of mining heritage.

Although Romania disposes of a significant number of technical museums, the analysis conducted revealed that a low number of museums strengthen their cultural function by generating significant economic effects for the local community. This is mainly due to the faulty manner of promotion of the museums, which also generates a low number of visitors. In addition to the limited promotion, there are the low admission fees, or even no fees at all (for instance the steam locomotive museum in the town of Reşiţa). 
As far as means of promotion of the Romanian technical museums are concerned, this action which should have been one of the most important marketing actions - is completely absent or little developed. This fact explains why certain technical museums go ignored by tourists (for instance the Romanian Railways museum in Bucharest). One other factor that contributes to the weak tourist traffic in museums is the absence of the minimal conditions for maintenance and development of the museums (the absence of curators and guides who would offer additional information to visitors; for instance, the steam locomotive museums in Reşița and Sibiu). Practically, the two museums are cultural symbols but their economic capitalization is null. The absence of guides in technical museums prevents an in-depth understanding of the museums and at the same time means an impossibility to measure the visitors' degree of satisfaction. On the other hand, the same museums are deprived of the basic form of profit (there is no admission fee), a situation that makes it more difficult to modernize the museum or restore the items in the collection.

The Mining Museum in Roşia Montană stands out among museums in Romania; its custodians are mining engineers who are acquainted with the cultural facts of the region and who are skilled at offering information on the cultural and technological importance of the Roman mining exploitation. The museum's tourist reception center also features informative materials on the history of mining in the Western Carpathians region, meant to offer additional information. On the other hand, the museum in Roşia Montană is also favored by the publicity of the conflict caused by a Canadian company's resuming mining work, which might cause severe damages to the natural and man-made patrimony. The heavy media coverage of this conflict meant that attention was turned, in the past few years, to the cultural importance of industrial heritage assets. These became the main arguments used in speeches calling for a stop of resumed mining work, due to the particular and even unique features of the mining site (pre-historical site, a very high degree of preservation of the mine galleries, and the additional cultural value resulting from the presence of other types of relics as well: the ruins of a Roman settlement and the Roman funeral site).

The similarities of initiatives in the field of cultural preservation and capitalization in Romania with those unfolding at European and even global scale reflect Romania's accession to a normal course alongside the countries that promote their industrial past and the specificity of industrial social communities seeking and defining their own identities shaped around the element that had a contribution, and still contributes, to their evolution, even in the post-industrial phase.

\section{Discussions}

The current, postindustrial, time marks a new phase in the evolution of industrial towns, reflected in the succession of economic reorganizations and the problem of converting abandoned industrial sites (Merciu, 2011). Decommissioned economic units are most frequently converted into technical museums (TICCIH National Reports on the Industrial Heritage).

Bulegato (2008) considers that museums dedicated to industrial units, by means of their links to the land, have their own unique cultural identity (Massarente, Ronchetta, 2004). The cultural conversion of industrial sites also has the role of evoking the memory of the local collectivity.

Industrial sites also become attractive from the point of view of understanding and observing the process of work in industry - "work watching" (Mc Boyle, 1994 cited by Iancu, 2008), be they the extractive, siderurgical, textile or foods industries. There are examples of each type of industrial facility in service where guided tours of the production process are organized. The employed population in industrial sector is characterized by a work output not seen in other fields of activity.

The present study also means to capture the effects of the recent economic and social transformations onto the cultural, at the level of the industrial towns that underwent the most dramatic changes. As far as the cultural part is concerned, the conversion of abandoned industrial sites into manifestly cultur$\mathrm{al}$ and touristic facilities reflects the recovery and restoration capacity of certain areas that apparently are deprived of economic value and tourist-attractiveness. Although the process of conversion of industrial facilities into touristic and cultural assets is more difficult to accomplish, and it started with a certain delay, in Romania, the present study captures the beginning and continuity of this complex process, which redefines industrial areas that underwent a functional reconversion. In this this context of profound economic and social changes, the patrimony is considered a useful instrument in redefining territories and cutting down the malfunctions of spaces that have undergone functional reorganization. Patrimony is an important vector in the preservation of territories (Verret, 1995), and at the same time it serves as a form of legitimizing the identity of social groups. Patrimonialisation can be defined as a process of reinvestment, respectively upgrading obsolete spaces.

Technical museums can serve as an instrument in revitalizing the economy of functionally-restructur- 
ing regions. A new type of model can be identified in the evolution of technical museums, that is, the ecomuseum, whose role is to capitalize on industrial heritage assets in situ. The interest in museum capitalization of material-culture assets generated by economic activities, typically traditional ones and going back a significant period of time, stems from the technological and cultural values of the exhibits. The new vision to lay out the current technical museums reflects their quality as a symbol feature of local culture. Thus, technical museums become a means of conveying a positive image of industrial towns, which can evolve towards a higher level of efficiency, and become cultural tourist centers and at the same time "sources" of definition of the local culture for future generations.

The implementation of the process of cultural regeneration at the level of industrial towns allows a progress in their course from the category of unaesthetic urban centers to localities that can offer a series of cultural landmarks, other than those we are used to. In time, cultural landmarks linked to the industrial patrimony proved to be genuine cultural attractions. Although we are accustomed to regard a tourist destination from the perspective of its esthetic meanings, as the idea of the beautiful is associated with tourism, the industrial heritage assets - although they do not fit in this category - tend to become frequently-visited tourist resources. This revalorization of urban areas is based in an exploitation of creativity, starting off from the principle that culture is the force bringing about a multiplication of jobs (Sasaki, 2010, Homadovski A., 2009).

Recent museums also stand apart from the older ones by their capacity to surprise and re-surprise tourists visiting them. The matter of modern museums also touches on another delicate problem, that is winning over the local community as domestic tourists. Current museums tend to escape the stability and static stance of classical museums.

The success of a museum is visible and viable if the museum is strongly anchored in the local culture and history. It is also necessary to get the local community involved in establishing and maintaining the museum, so as to easily convey to tourists its cultural importance, and success is translated by the inflow of tourists who validate the cultural importance of the respective tourist destination.

Cultural and touristic capitalization of an industrial site sweeps along other related elements into the touristic process: for instance workers' boroughs, which are a social expression of the process of industrialization. These areas were humanized by the presence of employees who made that activity possible by means of their work and sometimes the sacrifice of their very lives. This explains the presence, in most technical museums, of a section that refers to the social side of that activity.

In virtue of their cultural function, technical museums are included in the category of man-made tourist resources, a fact that can favor their inclusion in the development strategies of the areas hit by economic reorganization, having a well-defined role and place in the system of touristic capitalization of those regions.

The change of the positive image can also have an important role, later on, in winning over investments in various economic activities.

The assets "created" by industry allow placing them in the limelight by means of their urban restoration process as defining elements for the history and culture of industrial areas (Merciu, 2011). The conversion of closed mines into theme museums and their inclusion in the tourist circuit ensure the preservation of the elements of local industrial culture and at the same time acts as an opportunity for the sustainable development of the urban areas that have been functionally reorganized. Abandoning mining facilities brings about, in time, the steady deterioration of these assets that evoke the industrial past (Corti, 1991, Holichy et al, 2010) and it would mean a loss in both material and cultural terms, because the technical and industrial patrimony assets are considered components of the national cultural heritage.

Urban restoration actions are meant to avoid the deterioration of industrial buildings and to launch measures to convert them into cultural spaces, with the main goal of displaying technical and industrial patrimony assets (buildings, machines and industrial installations, tools and transport infrastructure, etc.). At the same time, urban restoration actions must also be directed at reconditioning the buildings that compose the old workers' boroughs or the modern residential complexes, deteriorated by the passing of time, which define the social meanings of the industrial patrimony.

\section{Conclusions}

The diversification of the typology of technical museums is due to the influence of the major changes that occurred at local and global scale in the past three decades, in both economic and social terms. Opening up towards the preservation and capitalization of industrial patrimony assets from a museum perspective, nowadays, reflects a variety of types of technical museums.

One can notice in Romania there is a spatial arrangement of technical museums in terms of the important industrial centers across the nation, some of them preserving the industrial patrimony assets that 
act, in the current postindustrial time, as cultural tourist attractions.

Establishing technical museums in industrial areas that have undergone functional restructuring it is an instrument in the process of cultural regeneration, which, on the one hand, ensures a continuity of industrial patrimony assets, and on the other hand contributes to reviving the local economy, by including them in the tourist circuit. Ensuring a proper cultural management can turn the industrial site converted into a museum in an outstanding cultural tourist attraction that can win over a significant number of tourists.

The cultural regeneration of industrial towns also contributes to the creation of the towns' touristic image. There are numerous examples in Western European countries where urban renovation actions contributed to enhancing the attractiveness of industrial towns by converting them into centers of industrial culture.

The conclusions of the study reflect the fact that, although there is a relatively high number of technical museums, nationwide, few of them that ensure a sustained economic support to local communities. This situation is a direct result of inadequate management of museums, which keeps them out of the limelight, although some of them are unique in Romania.

It is necessary to rethink the organization of technical museums so that they would represent one of the useful instruments in implementing the strategic goals of development of industrial areas that have undergone functional reorganization.

\section{Acknowledgment}

This study was conducted with the support of strategic programs POSDRU /89/1.5/S/58852 "Post-doctoral program for training of researchers in science" and POSDRU/107/1.5/S/80765 "Excellence and interdisciplinarity in doctoral studies for an information society" co-funded by the European Social Fund by way of the Operational Sectoral Program for Development of Human Resources 2007-2013 and Territorial Management Based on Growth Poles' Theory (UEFICSU-PNIIIdei, 1950).

\section{References}

Bianchini, F., Parkinson, M. (eds.) 1993. Cultural Policy and Urban Regeneration: the West European Experience. Manchester University Press, Manchester, Bianchini F., Remarking European cities: the role of cultural politics, pp. 1-20.

Bulegato, F. 2008. The museums of enterprises. From the industrial arts to design. Carocci Publishing House, Roma, 208 pp. (in Italian).
Cercleux, A.-L., Merciu, F. C. 2010. Technical and industrial heritage in Romania. Capitalization, risks and prospects of development. Annals of Professional Association of Geographers of Romania 1, 1, 45-54. (in Romanian with English summary)

Corti, B. 1991. Industrial Archeology, Puntografico Spa Publishing House, Brescia, 398 pp. (in Italian).

Đurović, P, Đurović, M. 2010. Inventory of Geoheritage Sites - the Base of Geotourism Development in Montenegro. Geographica Pannonica, 14, 4, 126-132.

Geronimi, M. 2006. Urban identity and spatial dynamics in a post-industrial city: Montreal and Hochelaga-Maisonneuve. Norois 199, 2, 45-60.

Grandi, M. A. 1991. The city after the crisis. Urban reconversion and new processes of capitalization: a check on the area of Prato, Alinea Publishing House, Florence, 256 pp. (in Italian)

Gorjup-Kavčič, M., Režun, B., Eržen, U., Peljhan, M., Mulec, I. 2010. Natural, Cultural and Industrial Heritage as a Basis for Sustainable Regional Development within the Geopark Idrija Project (Slovenia). Geographica Pannonica, 14, 4, 138-146.

Holický, M., Jung, K., Marková J., Sýkora, M., Flo, A., Kvaal, K., Thiis, T. 2010. General methodology for probabilistic assessment od industrial heritage structures. International Grant, available at www. heritage.cvut.cz/file_download/48/general_methodology.pdf.,accesed on 16.07.2011

Homadovski, A. 2009. Transformations in cultural institutions - contemporany museum destinations and influences of industrial branding values. Prostor $17,2,389-395$.

Iancu, F.-C. 2008. The perspective of industrial tourism development in the Petroşani Depression through industrial heritage capitalization. Journal of the University of Dimitrie Cantemir, Târgu Mureş, 560-567. (in Romanian, with English summary).

Lorente, P. 1996. The role of museums and the arts in the urban regeneration of Liverpool, Center for Urban History, Leicester, $184 \mathrm{pp}$.

Massarente, Al., Ronchetta, C. 2004. Ecomuseums and landscapes, experiences, projects and research on the material culture, Lybra Imagine Publishing House, Milano, 351 pp. (in Italian).

Merciu, F.-C. 2010. Spatio-reconfiguring modeling under the influence of mining activity of the settlements of Petrosani Depression. Geograful review 2, 3, 31-38. (in Romanian, with English summary).

Merciu, F.-C., Stoica, I.V. 2010. Tourist capitalization of industrial heritage elements: a strategic direction of sustainable development. Case study: the Petroşani Depression. Geojurnal of Tourism and Geosites 5, 1, 62-70.

Merciu, F.-C. 2011. Management of functionally-reorganized spaces. Regeneration of industrial areas in 
the Petrosani Depression through the development of tourist ventures, Universitară Publishing House, Bucharest, 262 pp. (in Romanian with English conclusions)

Merciu, G.L. 2011. Steam locomotive museum - a symbol of Resita municipality. Geograful review, 3,1-2, 71-74, Universitară Publishing House, Bucharest (in Romanian, with English summary)

Preite, M., Maciocco, G. 200o. From mine to museum. The recovery of the mining sites in Europe, Alinea Publishing House, Florence, 191 pp. (in Italian)

Sasaki, M. (2010). Urban regeneration through cultural creativity and social inclusion: rethinking creative city through a Japanese case study. Cities, 27, S3-S9.

Scott, C., 2007. Advocating the value of museums, Intercom/ICOM, Vienna, 2oth August 2007, available at www.intercom.museum/documents/CarolS cott.pdf, accesed on 03.04.2011.
Unguraş, A. I., Merciu, F.-C., Stoica, I. V. 2009. Târgu Ocna Salt Mine: premises harnessing the balnear and cultural-industrial potential. Bulletin Petroleum - Gas University of Ploieşti, Economic Sciences Series 61,4, 69-80.

Verret, M. 1995. Chevilles ouvrières, Éditions of Atelier / Éditions ouvrières, Paris, 254 pp.

Veschambre, V. 2007. Le patrimoine: un objet révélateur des évolutions de la géographie et de sa place dans les sciences socials. Les Annales de Géographie 656, 361-381.

2009. Industrial Archeology, TICCIH National Reports on the Industrial Heritage, edited on the occasion of The XIV the International TICCIH Congress in Freiberg, Germany, 30 $0^{\text {th }}$ august to $5^{\text {th }}$ September 2009. 